\title{
Dr Seuss on Sex
}

\author{
Richard W Casey MD FRCS Urology, Editor-in-Chief
}

He took off his pants, and gave it a stare And he said to himself, "This is going nowhere" "It used to get hard, it just ain't fair" "I'll check with my doctor, he gives a care"

For all the patients in ED land In long lines they would have to stand For there were no good pills To cure their ED ills For they would learn a new set of skills

"Help me, doc, my wife is still keen"

"It's all in your head, not the small one between Concentrate on your partner, progress will be seen Imagination is important, to be a good hub Kind words, attention and a back rub"

This advice was quite useful till about one nine eight zero Until there appeared in a Vegas Casino An unusual character, not a drag Queeno But a doctor of sorts, whose mind was quite quick "Welcome everyone, I'm the Stick in the Dick"

Now The Stick in the Dick had the answer for all No longer a soft penis, they all would stand tall "For my potion restores to the organ its stiffness Look at my hard penis, you're all the first witness"

For ten years there was joy back in old ED land There wasn't a soft penis in anyone's hand Stick in the Dick and his turgid conquest Had not noticed that he had created a mess Sure, dead penises he had brought back to life Only to neglect one person, the penis's wife "Too mechanical" they said, "it's like riding a bike"

"We need something more natural and it is a factual that actually sex is just in our head"

"A pill would be better to make you slow down And do something sexy while waiting around A back rub and some hugging

\begin{abstract}
Along with some tugging and a little less bugging that we should go down."

Finally a blue pill came on to the scene And Stick in the Dick we started to wean It was time to appreciate a simpler solution Not having to titrate to another dilution Viagra created a sexual revolution
\end{abstract}

Most men could now function when asked to perform Whether 60 or 70 or at Shady Lawn

And to their doctor's offices they were drawn Advertisements told them they could belong 'Good Morning, Good morning' was more than a song There's money in drugs that can make members long

Now Thing 1 and Thing 2 have entered the race Viagra they hope one day they'll replace

Thing 1 is called Quick Dick

For it works a bit quick

Thing 2 is La Weekend

Wishful thinking say most men

..... then there's this thing about partners again

"There must be a pill that can make my wife randy So I don't need flowers, jewels and the candy The Window of Opportunity I am afforded Stays closed unless my wife is well courted And who has the time once hockey has started?"

If old Dr Seuss had written about sex Imagination, adventure and togetherness His pictures and rhymes would surely express ED land, a place that is magnificent No vacuums, pills or things to inject Of course, his characters aren't anatomically correct!

Anamaria, Carol, Monica, Nadine Catherine, Isabella, and even Christine Work hard for their products, to make MDs keen 'Read our statistics, for statistics don't lie' 'Ours is the best drug for your patients to try'

The Male Health Centres, Oakville, Ontario

Correspondence: Dr Richard W Casey, 407-1235 Trafalgar Road North, Oakville, Ontario L6H 3P1. Telephone 905-338-3130, fax905-338-3150,e-mail drcasey@malehealth.com 